Versión "postprint" del documento publicado en:

Meir, Christopher. The Danish producer in an era of convergence and globalization: An interview with Meta Louise Foldager. Journal of Scandinavian Cinema, Vol.6, N.1 (2016) pp. 39-51

(C) Intellect 


\section{The Danish producer in an era of convergence and globalization: An interview with Meta Louise Foldager}

\begin{abstract}
Producers are seldom the focus of screen studies research, but this interuiew with Danish producer Meta Louise Foldager demonstratesjust how useful these vital crea-tors are to understanding the Scandinavian film and television industries, both of which currently find themselves in periods of rapid change. The interuiew focuses on three themes: the differing roles that the producer plays infilm and television produc-tion; the state of the Danish film industry; and the burgeoning television drama indus-try in Denmark. Throughout these three sections, Foldager discusses how local and global forces are influencing her work and that of her colleagues in both industries.
\end{abstract}

\section{INTRODUCTION}

Producers, particularly those working outside the Hollywood studio system, remain relatively anonymous in film and television studies, with scholars in the two fields tending to focus on directors and writers as the central creative talents in their respective media. While scholars

\section{KEYWORDS}

film industry television industry transnationalism film producer Danish cinema 
1. In his seminal work The Genius of the System. Hollywood Filmmaking in the Studio Era (1989), which helped to inscribe the producer and the studio

executive as central to understanding creativity in the Hollywood system. Other influential discussions of producers within the Hollywood system can be found in Tino Balio's United Artists Vol. 1 and 2(1987a, 1987b) and David Bordwell et al's The Classical Hollywood System (1986).

2. Recent attempts to analyse the work of producers outside Hollywood include Tom Whittaker's The Films of $E$ lías Querejeta. A Producer of Landscapes (2011), And rew Spicer and A. T. McKenna's The Man Who Got Carter Michael KOnger, Independent Produ ction and the British Film Industry 1960-1980(2013) and Beyond the Bottom Line. The Producer in Film and Television Studies (2014), a collection edited

by Andrew Spicer A. T. McKenna and Christopher Meir.

3. Although Mankell is more famous as a novelist, he also routinely features in discourses about Swedish television drama due to his work as head writer on Wallander, which of course was based on his novels. such as Thomas Schatz have ensured that names like Irving Thalberg and David O. Selznick are (rightfully) at the forefront of our understanding of Holl $_{\mathrm{vw}}$ ood cinema, ${ }^{1}$ few scholars can speak with equal confidence of the key producers in other world cine-mas, including those of Europe. In recent years there have been attempts to address this shortcoming in the critical literature and to draw more attention to the work of important non-Holl ${ }_{\mathrm{yw}}$ ood producers, ${ }^{2}$ but we are still far from fully appreciating the significance of producers' labour or their usefulness for understanding film and television culture.

This general neglect has also been manifest in studies of Scandinavian cinema and television where auteur figures such as Ingmar Bergman, Lars von Trier and Henning Mankell ${ }^{3}$ have dominated historiographies of film and television drama. The following interview hopes to showcase the potential for taking a different methodological approach and placing the producer at the centre of the discussion, a decision that is all the more compelling given the clase proximity this particular producer has had to both auteur directors and celebrated television writers throughout her career. The following piece is derived from two interviews the author carried out with Meta Louise Foldager, a Danishbased producer whose careers in both media have involved a great deal of transnational deal-making and collaboration. As such, Foldager is uniquely positioned to illuminate many of the key facets of the contempo-rary Zeitgeist in the Scandinavian screen industries, which are seeing unprec-edented levels of globalization in terms of industrial and creative collaboration as well as convergences of many kinds between film and television drama, with the latter $\operatorname{ar}_{g u}$ ably becoming the most globally visible stage for screen artists from the region. By highlighting Foldager in her own words, this article seeks not only to provide a new perspective on these vital issues for scholars in the field but also to remind them that producers are a largely untapped scholarly resource for understanding film and television culture.

\section{CAREER OVERVIEW}

Befare delving into the discussion with Foldager, sorne back ground on her career is in arder. Producing became something of a calling for Foldager in her teen years when she initially set out, like many aspiring film-makers, to direct film and theatre projects with classmates, only to realize that she enjoyed organization and collaboration more than directing. This, combined with her manifest talents in these areas, led her to pursue formal training in produc-ing, but discovered that she did not fit the standard age profile for students in the producing de gree course at the National Film School of Denmark (at 17, she was told by school administrators that the average age of beginning students was 23). Rather than applying to the course, she pursued a de gree in Cinema Studies elsewhere and taught herself the practice of producing through reading, working in the local industry and eventually doing fieldwork in Los Angeles for her de gree.

From these beginnings, Foldager landed her first producing job as an intern with Zeitgeist, a now defunct micro-budget independent company in Denmark. From this position she rose through the ranks, performing virtu-ally every task at the company at one point or another as they put together a feature, the science fiction film Skyggen!Webmaster (Nielsen, 1998), and co-produced another, the comedy Regel No. 1/Rule No. 1 (Ussing, 2003). Her achievements at Zeitgeist ultimately drew the attention of Nimbus 
Films, where Foldager received her first full producing credit on a feature for Kongkabale/ King's Game (2004t the first in a string of successful partnerships with director Nikolaj Arcel. Foldager went on to make two more features with Nimbus (Nordkraft/Angels in Fast Motion [Madsen, 2005] and Liv [Faisst, 2006]) befare Lars von Trier asked her to produce DirektOren for det hele/The Boss of It All (2006) for Zentropa. The partnership with von Trier put Foldager on the intemational stage and she went on to produce two of the director's most controversia! films: Antichrist (2009) and Melancholia (2011). Contrary to the director's public image as a difficult, self-involved artist, Foldager compares working with von Trier to 'extreme sports, but in a good way', calling it 'the most rewarding experience of [her] career'. Besides these high-profile films, Foldager produced nine other features at Zentropa along with a number of shorts and a television series, while serving in a variety of roles on assorted other projects. The work in features during this phase of her career included three further collaborations with Arcet with En kongelig afféer/A Royal Affair (2012), the most recent film they have made together to date, gamering an Academy Award nomination for Best Foreign Lan $_{\text {gu }}$ age Motion Picture.

Foldager struck out on her own as an independent producer in 2012, forming Meta Film first and later, in 2014, establishing SAM Productions with Adam Price (creator of Borgen/'The Fortress' [2010-2014]) and S0ren Sveistrup (creator of Forbrydelsen/The Killing [2007-2012]) with an eye towards produc-ing high-end television drama. Meta Films has thus far been involved in four feature films and a television series, with 2015's Sommeren 92/Summer of '92 (Barfoed, 2015) its biggest box office hit in Denmark to date. SAM, which was set up with funding from French film and television distributor Studiocanal and other investors, recently landed its first commission for Adam Price's new series Rides Upan the Storm, which will air in 2017 and 2018.

Given the current state of the Danish screen industries and indeed those of Scandinavia at large, Foldager's experience and current projects make her an invaluable source for scholars in the field. As such, the interviews ${ }^{4}$ have been edited to focus on three themes that are especially pertinent to scholarly debates. Toe first is concemed with the work of the producer in both film and television and how the demands of that role are changing in an age of conver-gence between the two media. The second pertains specifically to the Danish feature film industry as seen from the trenches at Meta Film. The final section deals with the creation of SAM and what this company tells us about the global forces that are shaping this segrnent of the screen industries.

\section{THE WORK OF THE PRODUCER IN FILM AND TELEVISION}

The labour of the producer is central to all aspects of screen media production and consumption, but this labour is barely mentioned within popular and academic discourses concerning film and television. Such collective underap-preciation of this pivotal fi ${ }_{\text {gu }}$ re has had the effect of distorting our understanding of film and television history. Perhaps one of the reasons for the disregard of the producer is that the role itself is difficult to define and very seldom even consistent from film to film, or indeed from producer to producer. If producers themselves cannot agree on what they do, how can the general public or media scholars begin to appreciate their work? But we should not be detened by the ambiguities of the title of producer or, in the case of television especially, that of executive producer. Instead we should take these as vital entry points for understanding how the creative process of media production transpires.
4. Two main interviews took place between the author and Meta Louise Foldager, both via Skype, the first on 8 October 2015, the second on 15 December 2015 In sorne cases, clarifications and additional information were supplied to the author via e-mail The author would also like to gratefully acknowledge the assistance of Mandisa Pantin in transcribing the interviews and Nadika Johanneson for facilitating communication with Meta Louise Foldager throughout the process of interviewing her and preparing this manuscript. 
In the amorphousness that characterizes much production labour generally accepted to include attention to the commercial dimensions of a project as well as creative ones such as script development and the 'packag-ing' of creative talents - there remains a great deal of scope for a producer to assert influence over a project in ways ranging from standard definitions of the role to methods and skills that often defy precise articulation but nonetheless are potentially fascinating to students of the respective media. Examples of these intangible skills can range from taste, persuasiveness and salesmanship to sensitivity, leadership and resourcefulness. Indeed, one of the most reveal-ing questions an interviewer can ask of a producer is to define his or her role beyond a mundane list of the tasks carried out, with two producers seldom giving the same response. This question is put to Foldager below and her answers tell us a great deal about making film and television in Scandinavia, particularly when it comes to working with auteur talents, whether they be celebrated directors or showrunners, and multiple stakeholders who invariably band together to fund much independent production in the region.

Foldager' s career has been contemporaneous with the emergence of the socalled 'golden age' of television drama, an age with special importance to Scandinavia, which has been home to seminal European television dramas including Lars von Trier's medical show Riget/The Kingdom (1994), the politi-cal drama 'The Fortress', and perhaps most famously, the 'Scandi-Noir' crime series that have achieved global fame, including such titles as Wallander (2005-2013), Broen/Bron/The Bridge (2011-) and The Killing. This Zeitgeist has shaped Foldager' s career in profound ways, particularly with the launch of SAM, and she is thus well placed to understand the differences between the two media. If one of the defining characteristics of this current age of television has been the migration of key talents such as directors, writers and stars from the big screen to the small one, we must also begin to think about producers in a time when seemingly every production house is launching a television division. Far from being consistent across the two media, the role of the producer actually changes in ways that are simultaneously obvious and subtle, and Foldager here points out sorne of these. In industries as small as those of Scandinavia, understanding the actual difficulties inherent in moving between the two media is crucial to assessing the value of producing talent and appreciating the challenges of educating the next generation of producers who are required to advance and develop industries and drive innovation in the respective art forms.

CM: Do you think the young film producing talents in Denmark have the skills that they need? What do you think are the key talents required of producers in Denmark ar Scandinavia specifically?

MLF: I think the emerging producers are very good on the whole. The most important skills as a producer, though, are skills that you do not leam in school. They are interpersonal skills that you leam on your own. The most important for me can be best summed up with the German expression Fingerspitzgefühlliterally, 'the sensitivity of the fingertips'. This means when you go into a room, when you work with a director, how you are with the director of the film on any given day. What do you say in front of a financier? Is this person in a good or bad mood? Can I hold forth? Can I negotiate? If I say this word to this person, will they jump at it? If I pitch this project to this person, what will this person's interest actually be? Would they feel connected to the material? 
That sensitivity towards other people is Fingerspitzgefühl. I think it's a wonder-ful word and I think it's a very important skill to be able to read people, to use that in your work and with people who are on set or in a financing meeting or reading a script - you can use it in everything. You can know everything about the media world, everything about financing, everything about putting together a budget. If you do not have the right interpersonal skills, you are going to be in trouble.

CM: Having produced two television series befare forming $5 A M$ and now being in development with severa[ projects at 5AM, what in your experience are the majar differences between producing far television versus producing farfilm?

MLF: Many of the differences stem from the scale of producing a longer format for television. There can be ten to thirteen episodes and sometimes they tum out quite fast and you need to keep up the pace. For example, you may need to keep notes and to read six drafts of Episode 3 and still remember what changes are made in Episode 2, in the six drafts of Episode 2, and so on. There's a whole system that is just so different from when you develop a script for a movie.

There is a lot to leam between being a movie producer and going into television also on the legal side. Deals with the television networks, deals with the actors, and so on. How long do you keep the actors [under contract] for? In the US, they hire them for six seasons, six years of work when they enter into the first season. What do the actors, producers, writers or directors expect in terms of royalties and residuals? How do you pay a writer working for five years instead of for one movie script? Everything is different.

CM: Would you like to see more formal, specialist training made available in these television producing skills?

MLF: I think you need to be hands on. I think you need to actually experience a television series in production. Of course sorne of it can be leamed. On the legal side a lot of skills can be leamed and at least knowing where the differ-ences are can be taught.

\section{ISSUES IN CONTEMPORARY DANISH FILM PRODUCTION}

While much attention has been focused on Scandinavian television drama in recent years, the film industry has undergone important changes - sorne of which have been arguably occasioned by developments in the realm of television - and produced many important works in its own right. Producers often straddle the artistic and commercial worlds that surround and shape media production and are thus uniquely positioned to provide insights into how industries change and how those changes impact the works that end up being made. Over the course of her career with Nimbus and Zentropa, Foldager worked on sorne of the most important Danish films in recent memory. Since the launch of Meta Film, she has come even more directly into contact with the many forces shaping the Danish industry, including those emanating from home and abroad.

Much has been said in debates on Danish and European cinema about the ongoing dialectic between the national and transnational and how this influences film-makers. In the age of increasing governmental austerity throughout the continent that accompanied the financial crises of the late 
5. For a statistical documentation of the growing number of English-language films being made in nonanglophone European countries, see Laétitia Kulyk (2014)

6. 'Giving notes' is an industrial practice in which producers and studio executives provide suggestions (and sometimes orders) for changes to script drafts.

7. A first look agreement is one in which a distributor and/or sales agent - SF in this case - provides a producer with funds for overheads and the development of projects in exchange for the right to have the first opportunity to sell and/ or distribute the producer's completed projects. 2000s and early 2010s, which saw a reduction in public subsidies for produc-tion, many European film-makers have increasingly turned to the interna-tional marketplace and production in English in pursuit of larger audiences. ${ }^{5}$ Among the man y Scandinavian film -makers to tread this path have been Thomas Vinterberg, Susanne Bier and Lars von Trier. But as film-makers across the region, and indeed the continent, have rushed into this segment of the market it has become crowded. Competition for financing and talent has seldom been more intense than in recent years, perhaps triggering a return to the local amongst many. Even as this is occurring, many 'local' films are surprisingly global in their production histories and international circulation. The following excerpts deal with Foldager's experience of this complex situa-tion, beginning with a discussion of her most recent film Summer of '92, a look back at the Danish national football team that won the 1992 Euro football tournament against all odds and expectations.

CM: Summer of'92 is something of a paradox in that it is a co-production and you have a big international sales agent on board - London-based HanWay Films - but in a way it is your most locally themed film to date in terms of being a Danish story with the national football team's great success in the Euro '92 competition. How's it going in terms of international sales far the film? I know it did quite well at the Danish box office, but how is it travelling?

MLF: I don't have the financia! projection for that as yet, but another film I produced, A Royal Affair, was also very Danish as it was about the Danish King and Queen and Danish history, but it travelled very well. This one seems harder to sell, which surprises me, and the team, but we will see.

CM: The transnational collaborations on Summer of '92 were really multifaceted; could you talk about sorne of these? Specifically, I am thinking of the creative collaboration with British producers and what it was like to work with British sales agents HanWay.

MLF: The UK producer Kris Thykier was the one who brought the idea to me and he had already got the writers and the director for the project. He was looking for a Danish producer to produce the movie with. 1t's been a pleasure working with Kris and it's also been a whole new way of working for me. We would be in Denmark where the way we do a trailer is different, the way we give notes ${ }^{6}$ is different. Then of course there is stuff that is still the same. Also, in Denmark every producer works their own way and so on but I think there is a cultural difference. Kris is actually half Danish but he grew up in England so he is also British. There is a difference in how you do an e-mail in the two countries. There is a similar difference between France and the UK. There is a difference from Denmark to Sweden and so on, but I enjoy these differences.

CM: I wanted to ask about your professional and commercial relationships because this is an important part of the work of the producer, to develop and maintain such relationships. Meta Film has a first look deal with Svensk Filmindustri (SF). ${ }^{7}$ Is that just far the Danish market ar is that far all across Scandinavia?

MLF: Denmark.

CM: When it comes to international sales, do you have an ongoing relationship with HanWay? 
MLF: No. We are working with a lot of different sales agents. We work with [French-based] Indie Sales on another movie (Sorgenfri/What We Became [Mikkelsen, 2015]), we worked with Celluloid Dreams on another, we worked with SF on another one, we even went with Nordisk Films. For every movie it is a new sales agent. We do quite different kinds of movies and every movie is its own movie and we want to be sold by the ones that are best assigned to that specific movie and I haven't found reasons to change my mind about that yet.

CM: So you decide on a project-by-project basis. Currently, one hears all sorts of horror stories about the market far pre-sales and other types of funding arrange-ments. Is this impacting Meta Film?

MLF: Danish movies have very seldom been sold on intemational presales and I have a few projects that are being sold in this way. Sales agents are saying that their business is slow and I think in general the movie business is really slow at this moment, due largely to the popularity and profitability of television series production.

CM: Is this driving you towards English-language production or working with English-language stars?

MLF: No. The intemational market is even worse than the Danish market. In the Danish market we still have the Danish Film Institute and quite a good home market for the movies, so we can find a distributor. I have a deal with SF and we still have television stations that invest quite a bit of money in Danish films. We have quite big chunks of financing for Danish products right there, so to move into intemational English-language movies is just moving into an even worse market. This has the effect of attracting producers to more local material.

\section{TRANSNATIONAL TELEVISION DRAMA AND THE DANISH PRODUCER: FOUNDING SAM}

It is now customary to speak of the 2010s as the 'golden age' of television drama, with works such as Breaking Bad (2008-2013), Mad Men (2007-2014) and Sherlock (2010-) amongst many others dominating world screen culture in unprecedented ways, often attracting the traditional audiences of middle-brow art cinema as well as many of the creative talents who would have once been working in film. We hardly need a reminder of just how central Scandinavia has been to the European branch of this small screen revolution. Wallander was a forerunner to the global successes that were 'The Fortress', The Bridge and The Killing, with many of these series exerting global influence by virtue not only of their own circulation but also via remakes in various countries.

Like many film producers, Foldager has moved into this segment of the market, which continues to experience a gold rush of sorts with major broad-casters, pay-television companies and digital platform operators like Netflix all searching for the next big series. Competition in this arena has created opportunities for producers, but it has also increased costs as audiences expect ever higher production values. This has led to a situation in which television drama, once supposed to be thoroughly local in orientation, must necessarily have access to intemational markets for both production finance and sales and distribution opportunities. Independent producers across Europe have in recent 
years been seeking sales partners while commissioning broadcasters are busy co-producing with their counterparts in other countries and/or forming their own distribution arms in order to tap global markets. Seeing opportunities in this segment of the market, Foldager and collaborators and celebrated writers Adam Price and S0ren Sveistrup set out to establish a production company. Given the conditions in the marketplace, they needed to find an intemational partner who could provide development finance and distribution support. They eventually found this partner in the form of Studiocanal, the production and distribution arm of the French pay-television company Canal Plus. Studiocanal was up to this time largely a film company but had since 2012, like many film studios, been diversifying into television drama and was eager to find produc-tion partners in Europe. Scandinavia seems to be of especial interest to the company; in addition to the partnership with SAM, they have also inked production agreements with SF and Swedish film director Tomas Alfredson's Spark TV. SAM Productions - named after the first letters in the names of the three partners - was established in 2014 and picked up its first commission shortly thereafter in the form of Rides Upan the Storm, a series to be written by Adam Price and broadcast on DR, Arte France and Arte Germany in 2017.

As these global pressures begin to be felt in the realm of Scandinavian television drama, SAM is an ideal case study for understanding what forms of collaboration are possible. Globalization, particularly in the media world, is often seen as de facto Americanization, but SAM is partnering with a major European studio to support its global push. This partnership may thus far have produced only a commission for a Danish-set, Danishlanguage series, but SAM also has French-language, French-set projects in development (with Studiocanal sister company Canal Plus), a situation that speaks to a direct regional influence on the part of Scandinavian producers. But for all of its seeming Europeanness, SAM is also working on English-language US projects, again complicating the narrative of one-way traffic from America to the rest of the world that is depicted in most writing about globalization. In the following passages, we see once again that it is the producer who is best placed to observe and illuminate these global cross-currents as they are beginning to shape Scandinavian, and indeed global television culture.

CM: Can you talk about the role you are playing with 5AM and the place that 5AM has in the bigger picture of European television drama as well as its relation-ship with Studiocanal? How did you come to get involved with the company?

MLF: I have known Adam Price for many years. He used to be a commis-sioning editor at [broadcast network] TV2 in Denmark and [in that role] he actually put money into my first feature film, which was a political thriller [King's Game]. After that he wanted us to make a television series based in that milieu, but we didn't and Adam did it himself ['The Fortress'], but I kept that dialogue with him open and said that he owed me a television series. I met with him at sorne point every year and at these times I discussed with him a project to start when he was done with 'The Fortress'. Toen I heard about the success of 'The Fortress' and said to him that I thought he should test out what that could bring him intemationally, to find out befare he took another job for a television station or anyone else how much he was worth outside of Denmark. He said that was really interesting and asked me to find out. I also said to him that he should not make a series for anyone, not even for me; he should only do it for himself and he should make his own setup and should partner up with someone who was at his level. 
After a couple of months he called me and said that he had partnered up with SOren Sveistrup. They know each other very well, they'd been working together far many years as staff writers. They are very different people, both wonderful, but very different. I had never met S0ren befare but I said that's a really clever move and you two guys together could make a really strong base far a production house that would attract a lot of new projects and new writ-ers, and I think you could also attract investors, and they then asked me to try out that theory.

Befare SAM, I had done two smaller television series (Mikkel og Guldkortetl'Mikkel and the Gold Ticket' [2008] and Europamestrenel'European Champions' [2013]), Danish ones, but I've always been more into movies and I'm still into movies, but they asked me to test that out. I then started negotiating on their behalf and they asked me to run the company with them; we were going to start a company. I said yes to that - I was very happy about the idea - and then especially when I started negotiating with different possi-ble financiers, I realized that it was very possible to get investors. I negoti-ated with three different potential partners and ended up going with the Studiocanal deal.

\section{CM: How did you attract attention from Studiocanal?}

MLF: Adam had a series (that SAM still has) in development that Canal Plus was really interested in. So I think he had meetings with Canal Plus and half of the executives at the meetings were with Studiocanal. I reached out to them and they reached out to us and were very eager to meet.

CM: What's the advantage of working with a company like Studiocanal? I presume they provided you with startup development funds? Can you go into sorne specifics about the arrangements between your company and theirs?

MLF: Yes, they did provide startup funds. We started out with a business plan and a five-year plan, as television drama takes a lot of time to develop. It takes many years to write a television series, so if you start off with no money then you will be dead befare you are done with your first series. But more than the money, I think it is also really important to have an intemational perspective on all of our projects from the beginning and to have them looking at the financial side from the very beginning and be able to hear their opinions about our projects and which ones they really like and which ones are far which channels. lt's always very surprising and even fun to give them sorne projects that I think are really intemational and then they say 'no'; then there are others that I think are very local and they will reach out far it and think there is a great farmat far it. It is really refreshing, and it is making our work even more intemational than I had hoped, so that's really good.

CM: On Rides Upan the Storm, you've got three broadcaster partners. How do the economics work? Do the three of them together pick up the whole budget far the project and then the intemational rights are in the hands of Studiocanal?

MLF: Studiocanal is putting in a minimum guarantee ${ }^{8}$ and Arte [France and Germany] is paying license and equity investment and DR is also, of course, paying a substantial portian of the budget.

CM: What kind of budget do you have far Rides Upan the Storm? I don't need an exact figure, but is it at the high end far Danish language?
8. A mínimum guarantee is an advance on the part of the distributor against projected income from international sales. As the term implies, the producer may be entitled to further payments should the sales prove to be greater than the distributor's projections, but the producer is guaranteed to receive at least this sum. 
MLF:Yes.

CM: Is it comparable to an Englísh language production?

MLF:Yes.

$\mathrm{CM}$ : Are all the projects $5 A M$ is working on going to be in Danish?

MLF:No.

CM: So you are looking at some projects in Englísh?

MLF:Yes.

CM: And the writers 5AM is working with, are they all Danish?

MLF: No, they are French, English, American, Swedish, Norwegian and Danish.

CM: Interesting I noticed that 5AM has a French subsidiary.

MLF: The French subsidiary (SAM Le Franc;ais) was established in order to co-produce with Arte and also because we now have three French projects in development. One that we haven't announced yet with Canal Plus and possi-bly one with France Televisions and that's not been closed yet so we can't announce that yet, either, but it will be a French production.

CM: Do you find that it is difficult producing in a multi-language environment?

MLF:No.

CM: Do you speak French?

MLF: I understand French but I won't be speaking it. All of our internal discus-sions and communications are in English, as our contracts will be because it is pan-European. The biggest challenge is that you must rely on good writ-ers because there is just stuff that you cannot know. For instance, as a writer, you cannot write a simple breakfast scene set in Paris if you are Danish. You don't know what they eat for breakfast when they leave their homes, when they normally take their children to schoot etc. How do they greet each other there? There are just so many little things to think about. That's actually the biggest challenge: the fact that it needs to be authentic, that we need to be real and therefore we need to have writers that know those things so they have to be local. So that's why when we do a French television series, we will hire French writers. Directors can easily be from other countries and the producers and so on, but the writers and the actors have to be local.

CM: And are you pitching things to American companies? Are you looking at American broadcasters as commissioners?

MLF:Yes.

CM: How do they compare with working with the European broadcasters? Do you have to do pilots? Or 22-episode seasons?

MLF: We are not that far with them yet. We do have stuff in development with [American cable network] AMC, for instance, and they are not going to ask 
for parity. For now, the most difficult thing is the time difference [Laughs]. It's very pleasant to be working with them.

CM: Do you find it is getting a little bit scary out there in the ways in which a lot of the networks are seemingly cutting down on how much they work with independ-ents? AMC now has their own in-house AMC studios that they want to produce through so they can control the rights on anything they finance. I know [American cable network] AEE is doing the same in the US, as is ITV in the UK, which is buying up a lot of the production houses. Is that increasing the pressure on an inde-pendent like SAM?

MLF: No. We have different kinds of projects and so we would like to try out this American way of working. I think it is a good way of balancing the risk within the company to have different kinds of projects and also to just have more broadcasters to work with. That way, we have more partners out there that we can go dancing with. If I see that there is an opportunity and if we don't like the conditions that any one commissioner is requiring, we can go somewhere else. Having that position, of course, also helps in the negotiation so that we get good deals.

CM: It's not limiting your opportunities, this consolidation you're seeing with sorne of the big broadcasters?

MLF: Not at this point, no, because we have the possibility of doing some-thing else, so we can choose. If that was the only model and we could only be work for hire and never get to own anything ourselves, I would feel that it was a restriction. But we can actually choose and do sorne the American way and sorne the European way. In principle, I actually like that but I haven't done it yet so maybe you should ask me again in two years [Laughs].

CM: The fear with someone like ITV is that they are just commissioning less that is made by independents, and the same with the $B B C$ and others. By prioritizing their inhouse producers, they limit the number of hours that are open far independents. But it is interesting that you say that the global reach of SAM allows it to bypass this situation, that you can always take it somewhere else. Is it a good time to be a television producer with all of this global demand?

MLF: Yes, because I have S0ren and Adam, and so it is a wonderful time because right now the writer is the source of the business. You need to be close to the sources or someone else can come and then come pick them up and then ride with them. The structure that we have with a writer-centred production house is also what attracts other writers, because we not only have them in the house and in ownership but the working conditions for writers are good here because the company has been created by writers. S0ren and Adam know what it is like to be a writer, so they want to - and they under-stand that we need to - attract writers more than anything. That is what they are working on mainly, making this a place where all writers will want to be.

\section{REFERENCES}

Balio, Tino (1987a), United Artists, Volume t 1919-1950: The Company Built by the Stars, Madison: University of Wisconsin Press.

-- (1987b), United Artists, Volume 2, 1951-1978: The Company that Changed

the Film Industry, Madison: University of Wisconsin Press. 
Bordwelt David, Staiger, Janet and Thompson, Kristin (1986), The Classical Hollywood System: Film Style and Mode of Production to 1960, New York: Routledge.

Foldager, Meta Louise (2015a), Sk ype interview, 8 October. Buffalo, NY, USA and Copenhagen, Denmark.

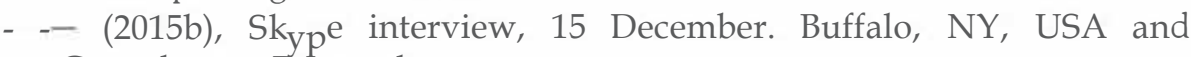
Copenhagen, Denmark.

Kulyk, Laetitia (2014), 'The use of English in European feature films: Unity in diversity?', in Mary Harrod, Mariana Liz and Alissa Timoshinka (eds), The Europeanness of European Cinema: Identity, Meaning, Globalization, London: IB Tauris, pp. 173-81.

Schatz, Thomas (1989), The Genius of the System: Hollywood Filmmaking in the Studio Era, New York: Pantheon.

Spicer, Andrew and McKenna, A. T. (2013), The Man Who Got Carter: Michael Klinger, Independent Production and the British Film Indust ${ }_{r y}, 1960-1980$, London: IB Tauris.

Spicer, Andrew, McKenna, A. T. and Meir, Christopher (eds) (2014), Beyond the Bottom Line: The Producer in Film and Television Studies, New York and London: Bloomsbury.

Whittaker, Tom (2011), The Films of Elias Querejeta: A Producer of Landscapes, Cardiff: University of Wales Press.

\section{FILM AND TELEVISION REFERENCES}

Arcel, Nikolaj (2004), Kong/cabale, Denmark/Sweden.

-- (2012), En kongelig affé:Er, Denmark/Sweden/Czech Republic.

Barfoed, Kaspar (2015), Sommeren 92, Denmark/UK.

Borgen (2010-2014, Denmark).

Breaking Bad (2008-2013, US).

Broen/Bron (2011-, Sweden/Denmark/Germany).

Europamestrene (2013, Denmark).

Faisst, Heidi Maria (2006), Liv, Denmark.

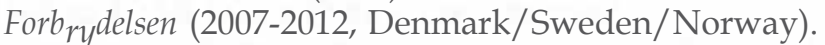

Mad Men (2007-2014, US).

Madsen, Ole Christian (2005), Nordkraft, Denmark.

Mikkel og Guldkortet (2008, Denmark).

Mikkelsen, Bo (2015), Sorgenfri, Denmark.

Nielsen, Thomas Borch (1998), Skyggen, Denmark.

Rides Upan the Storm (2017, Denmark/France/Germany).

Riget (1994, Denmark/Italy/Germany).

Sherlock (2010-, UK).

Ussing, Oliver (2003), Regel No. 1, Denmark.

von Trier, Lars (2006), Direkt0ren far det hele, Denmark/Sweden/France.

-- (2009), Antichrist, Denmark/Germany/France.

-- (2011), Melancholia, Denmark/Sweden/France.

Wallander (2005-2013, Sweden/Germany/Denmark).

\section{SUGGESTED CITATION}

Meir, C. (2016), 'The Danish producer in an era of convergence and

globalization: An interview with Meta Louise Foldager', Journal of Scandinavian Cinema, 6: 1, pp. 39-51, doi: 10.1386/jsca.6.1.39_1 


\section{CONTRIBUTOR DETAILS}

Christopher Meir is a CONEX-Marie Curie Fellow at the Universidad Carlos III de Madrid. He has published extensively on film and television industries, including the monograph Scottish Cinema: Texts and Contexts (2014) and a co-edited collection on the producer (Beyond the Bottom Line: The Producer in Film and Television Studies [2014]). He is currently working on a monograph on Studiocanal and its influence on the European and global film and televi-sion industries.

Contact: cmeir@hum.uc3m.es 